\title{
STUDI FENOMENOLOGI FINANCIAL LITERACY PENGRAJIN LOGAM DI PROPINSI JAWA TIMUR
}

\author{
Lilia Pasca Riani, Universitas Nusantara PGRI Kediri \\ bungalilia@gmail.com
}

\begin{abstract}
ABSTRAK
Tujuan dari penelitian ini adalah mendeskripsikan memetakan kondisi financial literacy pengrajin logam di Propinsi Jawa Timur. Adapun pendekatan penelitian menggunakan pendekatan kualitatif dengan menerapkan studi fenomenologi. Teknik pengumpulan data menggunakan wawancara mendalam dengan 8 pengrajin logam. Hasil dari penelitian ini adalah peneliti memperoleh 4 dimensi kondisi financial literacy pengrajin logam di Propinsi Jawa Timur, yaitu dimensi pengetahuan tentang istilah keuangan, dimensi manajemen uang, dimensi pencatatan keuanga dan sistem kerjan, serta penjelasan kondisi financial literacy pengrajin logam dari sisi pengetahuan tentang pajak.
\end{abstract}

Kata Kunci: financial literacy, pengrajin logam, Jawa Timur

\begin{abstract}
The purpose of this study is describing condition mapped of metalcrafters financial literacy in the province of East Java. The research uses a qualitative approach by implementing a phenomenological study. Data collection technique used in-depth interviews with eight metalcrafters. The results of this study are researchers obtained a 4-dimensional shape of a metalcrafters financial literacy in East Java, which is the dimension of knowledge about financial terminology, dimension of money management, the dimensions of financial record and system of work, and an explain the condition of financial literacy metalcrafters about knowledge about taxes.
\end{abstract} Keywords: Financial Literacy, Metal crafters, East Java

\section{PENDAHULUAN}

Di era konjungtur perekonomian yang tidak pasti sering kali yang menjadi korban adalah pengusaha kecil, bergelut dengan semakin mahalnya harga-harga kebutuhan, harga-harga faktor produksi, juga semakin langkanya bahan baku produks terutama bagi para pengrajin logam. Di propinsi Jawa Timur, kondisi tersebut juga tidak jauh beda karena sangat sulit memperoleh bahan baku dengan kualitas baik dengan harga terjangkau. Teori yang mapan menyebutkan bahwa perusahaan yang ingin berkembang haruslah memiliki daya saing dan value yang lebih, namun potret realita yang ada, para pengrajin logam ini memanfaatkan limbah logam dari industri besar untuk memproduksi berbagai macam alat pertanian, seperti cangkul, kapak, sangkur, dan lain sebagainya. Jikapun para pengrajin ini menggunakan bahan-bahan baku yang baru, pastilah berasal dari logam-logam yng diimpor dengan harga yang 
semakin mahal. Sangat sedikit sekali pengrajin logam yang memproduksi alatalat pertanian dan peralatan pertukangan yang dapat mengkespor produk mereka, selama ini produk logam yang diekspor berupa kerajinan anting-anting dan hiasan-hiasan atau dikirim ke Bali dan Jakarta untuk dibeli oleh turis asing.

Mayoritas dari mereka melakukan usaha tersebut meneruskan usaha dari leluhurnya, dengan kemampuan berinovasi yang rendah dan pengetahuan tentang pengelolaan keuangan yang minim. Disisi lain pemerintah kurang memberi perhatian pada pengrajin logam alat-alat pertanian dan pertukangan ini, pembinaan tentang peningkatan kualitas produk dan proses produksi sama sekali belum ada, pendampingan hanya pada sisi penyediaan kredit dan fasilitas keuangan, padahal para pengrajin ini kurang memahami tentang hal tersebut. Selain pembuatan alat-alat pertanian dan pertukangan, pengrajin logam yang memproduksi teralis besi yang cenderung lebih baik dalam berinovasi, pemenuhan bahan baku yang berkualitas, dan akses permodalan. Hal ini tidak lepas dari level pendidikan mereka yang lebih tinggi. Jika dibandingkan dengan pengrajin logam yang memproduksi alat-alat pertanian dan pertukangan yang hanya berijasah SD atau SMP, pengrajin teralis besi ini sudah memiliki ijasah SMA bahkan ada yang bergelar Sarjana Teknik sehingga sudah memiliki pola pikir keberlanjutan usahanya.

Berdasarkan gap fenomena diatas, penelitian ini berjudul "Studi Fenomenologi Financial Literacy Pengrajin Logam di Propinsi Jawa Timur", dengan tujuan memetakan dimensi-dimensi pola pikir tentang kebutuhan akan kepemilikan pengetahuan tentang keuangan.

\section{METODE PENELITIAN}

Penelitian ini menggunakan pendekatan kualitatif dengan studi fenomenologi sebagai metode nya. Studi fenomenologi merupakan salah satu metode yang digunakan dalam pemdekatan kualitatif yang melibatkan dan menemukan informasi berdasarkan pengalaman peserta/informan (Babbie, 1998). Sejalan dengan pendapat dari Arifuddin dan Saebani (2009) yang menjelaskan bahwa salah satu dasar filosofis yang berpengaruh dalam penelitian kualitatif adalah fenomenologis yaitu bahwa adanya kebenaran akan sesuatu dapat diperoleh melalui cara melihat fenomena atau gejala yang memancar dari obyek yang diteliti.

Proses penentuan infroman dilakukan secara purposive, tahap pertama peneliti browsing melalui internet tentang keberadaan pengrajin logam di kota/kabupaten di JawaTimur untuk memperoleh informasi mengenai nama pemilik dan alamat usaha, kemudian peneliti melakukan follow up dengan mengontak pengusaha kerajinan logam tersebut secara langsung dan memastikan informan tersebut sesuai dengan kriteria responden kemudian peneliti mengunjungi untuk melakukan wawancara mendalam dengan responden pemilik usaha kerajinan logam tersebut. Partisipasi informan dalam penelitian ini bersifat sukarela, dan para informan tidak menerima insentif khusus untuk partisipasinya.

Teknik pengumpulan data menggunakan wawancara mendalam dengan 8 responden pengrajin logam yang masing-masing memproduksi barang logam yang berbeda di lokasi yang berbeda. Pertanyaan dalam in-depth interview 
dikembangkan sendiri oleh peneliti berdasarkan hasil-hasil penelitian terdahulu yang relevan dengan topik/tema penelitian. Menurut Kaplan (2003) tujuan dilakukan in-depth interview adalah untuk mengidentifikasi pengalaman hidup/ketrampilan yang dimiliki informan dan tindakan-tindakan yang diambil saat menghadapi situasi tertentu secara spesifik. Rata-rata waktu yang dibutuhkan untuk masing-masing wawancara adalah 60-120 menit.

Data berupa transkrip hasil wawancara dan rekaman audio kemudian dipilih hal-hal yang penting (reduksi data) dan diinterpretasi oleh peneliti dengan mendeskripsikan hal-hal tertentu dan menyimpulkan untuk menjawab pertanyaan pnelitian.

\section{HASIL PENELITIAN DAN PEMBAHASAN}

\section{Demografi Informan}

Informan dalam penelitian ini terdiri dari 8 orang yang merupakan pemilik usaha kerajinan logam yang tersebar di Propinsi Jawa Timur. Adapun informan sudah menjalankan usaha ini lebih dari 5 tahun dengan mempekerjakan karyawan antara 5 - 20 orang.

Adapun barang logam yang di produksi dan kota asal pengrajin logam dipaparkan dalam tabel berikut dengan memberikan kode untuk nama :

Tabel 1. Daftar Responden berdasarkan jenis logam yang diproduksi dan kota asalnya

\begin{tabular}{|c|c|l|l|}
\hline No. & Nama & \multicolumn{1}{|c|}{$\begin{array}{c}\text { Jenis Logam yang } \\
\text { diproduksi }\end{array}$} & \multicolumn{1}{|c|}{ Kota Asal } \\
\hline 1. & A & Perhiasan Perak & $\begin{array}{l}\text { Kabupaten } \\
\text { Mojokerto }\end{array}$ \\
\hline 2. & B & Pengrajin kuningan & $\begin{array}{l}\text { Kabupaten } \\
\text { Bondowoso }\end{array}$ \\
\hline 3. & C & Alat-alat pertanian & $\begin{array}{l}\text { Kabupaten } \\
\text { Situbondo }\end{array}$ \\
\hline 4. & D & Kerajinan cor logam & Trowulan Mojokerto \\
\hline 5. & E & $\begin{array}{l}\text { Logam Mayangan, onderdil } \\
\text { mesin dan kendaraan bermotor }\end{array}$ & Kabupaten Pasuruan \\
\hline 6. & F & Teralis besi & Kabupaten Ngawi \\
\hline 7. & G & Alat-alat dapur & Kabupaten Nganjuk \\
\hline 8. & H & Etalase toko & Kabupaten Kediri \\
\hline
\end{tabular}

\section{Hasil Diskusi Mendalam}

Kepemilikan pengetahuan tentang keuangan merupakan kebutuhan mendasar agar terhindar dari masalah/masalah keuangan. Konsep financial literacy dalam hal ini sebagai penyebutan dari makna kepemilikan pengetahuan tentang keuangan.Remund (2010) menyebutkan ada empat hal mendasar dalam financial literacy, yaitu penganggaran, tabungan, pinjaman, dan investasi. Lebih lanjut menurut Susanti (2014) financial literacy terjadi ketika seorang individu dinilai cakap / literate yaitu mempunyai kemampuan dan keahlian yang cukup dalam mengelola sumber daya yang dimiliki untuk mencapai tujuan keuangan dan dalam mengambil keputusan usaha yang berkaitan dengan 
keuangan, baik mengenai pengalokasian dana ke pos-pos akuntansi tertentu, penentuan perbandingan besarnya hutang dengan kekayaan, perencanaan pembelian/penggantian aktiva tetap, perhitungan biaya tetap dan variabel, ataupun penetapan besarnya pajak yang dibayarkan pada pemerintah. Kelemahan-kelemahan ini banyak terdapat pada kalangan pengusaha mikro, kecil dan menengah terutama para pengrajin logam di Propinsi Jawa Timur.

Responden dalam penelitian ini sebanyak 8 orang dengan status sebagai pemilik atau pengelola usaha berbasis logam yang tersebar di beberapa kora/kabupaten di propinsi Jawa Timur. Adapun tingkat pendidikan mereka mayoritas lulusan Sekolah Menengah Atas atau sederajat sehingga hanya memiliki pengetahuan tentang pengelolaan keuangan pada tingkat dasar, meskipun seringkali dihadapkan pada situasi pengambilan keputusan yang rumit terkait perkembangan usahanya. Fenomena ini sejalan dengan teori yang dikemukakan oleh Lusardi dan Mitchell (2009) yang memotrek kompleksitas pengambilan keputusan ekonomi yang menitikberatkan dua tahap yaitu tahap mendasar dan tahap lanjutan. Tahap dasar meliputi pengetahuan mengenai perhitungan matematika, tingkat suku bunga, inflasi, nilai waktu uang, dan tipuan nilai uang. Sedangkan untuk tahap lanjut maliputi pengetahuan tentang pasar saham dan fungsinya, reksa dana, tingkat suku bunga acuan dan keterkaitannya dengan obligasi, perusahaan pengelola keuangan, pengetahuan tentang resiko-resiko finansial apabila menginvestasikan uangnya pada berbagai pilihan investasi saham atau obligasi,tingkat pengembalian uang jangka panjang, ketidakpastian fluktiasi nilai uang, dan diversifikasi resiko.

Hal ini juga dikuatkan melalui hasil penelitan yang dilakukan oleh Altintas (2011) bahwa perencanaan kebutuhan financial jangka panjang pada masing-masing individu berbeda porsinya terkait dengan pengelolaan kebutuhan medis, investasi pendidikan anak, perencanaan kebutuhan dimasa pensiun, berbelanja menggunakan kartu kredit, meminjam dana untuk kebutuhan liburan, dan membeli rumah/barang-barang elektronik dengan sistem cicilan.

Berikut adalah fenomena yang berhasil penulis potret dari keseharian responden terkait dimensi-dimensi kepemilikan pengetahuan tentang keuangan dan sikap mereka tentang pengambilan keputusan keuangan :

a. Dimensi pengetahuan tentang istilah keuangan

Berdasarkan hasil wawancara dengan responden pemilik usaha kerajinan logam, pengetahuan tentang istilah-istilah keuangan seperti perolehan laba, arus kas, aktiva lancar, dan tabungan/investasi sudah dimiliki.

Pengetahuan tersebut sudah mereka kenal selama belajar sekolah menengah atas. Meskipun begitu penerapannya dalam aktifitas sehari-hari, mereka mengaku lebih banyak belajar secara otodidak. Pembuatan laporan keuangan sederhana sudah dilakukan walaupun sering kali tidak dilakukan secara rutin perperiode (misal bulanan atau triwulanan).

Komitmen untuk disiplin inilah yang tampaknya masih kurang dimiliki oleh pemilik usaha kerajinan logam.

Hasil wawancata lebih lanjut diperoleh gambaran bahwa para pengrajin logam ini sudah memahami tentang pemanfaatan penggunaan aset secara maksimal, dan melakukan pekerjaan dengan sedikit biaya yang dikeluarkan. 
b. Dimensi manajemen uang

Memiliki pengetahuan tentang istilah keuangan mutlak harus dimiliki oleh siapapun pengelola sebuah usaha termasuk para pengrajin logam dan pengelola usaha kerajinan logam di Propinsi Jawa Timur. Menurut hasil wawancara, komitmen pengusaha kerajinan logam masih kurang karena pembuatan laporan keuangan dan analisis keuntungan dan kerugian berlum dilakukan secara periodik dan tepat waktu. Pemanfaatan fasilias kredit oleh perbankan sudah dilakukan sejak lebih dari 5 tahun yang lalu, namun besarnya nominal hanya pada kisaran 10 - 50 juta Rupiah dengan angsuran 3 - 4 tahun.

Bank yang menjadi langganan para pemilik usaha kerajinan logam ini adalah Bank Rakyat Indonesia (BRI) karena dinilai menerapkan bunga yang paling rendah dengan berbagai pilihan angsuran. Akan tetapi untuk pemakaian kartu kredit, semua responden menyatakan kuurang berminat karena transaksi sehari-hari masih bersifat tunai atau transfer antar bank. Pemahaman mengenai pemanfaatan kartu kredit masih sangat terbatas, mereka cenderung takut dengan alasan terbeban biaya bunga yang tinggi.

Terkait dengan kebutuhan penambahan modal ini, modal yang diperoleh melalui fasilitas kredit KUR digunakan untuk membeli berbagai fasilitas, seperti mesin gerinda, atau truk untuk mempermudah transportasi untuk mengangkut bahan baku maupun produk jadi.

Bahkan 7 dari 8 responden menyatakan belum mengetahui tentang pemanfaatan rekening giro pada Bank. Mengenai produk lembaga keuangan asuransi juga kurang diminati.

c. Dimensi pencatatan keuangan dan sistem kerja

Terdapat beberapa hal dalam menjelaskan fenomena yang terjadi pada para pengrajin logam ini terkait dengan pencatatan keuangan dan sistem kerja sebagai berikut :

1. Pencatatan keuangan

Dimensi ini melingkupi aktifitas pencatatan keluar masuk transaksi keuangan. Sebagian besar responden mengaku belum melaksanakan pencatatan keuangan secara teratur dan rigid, artinya masing banyak pengeluaran-pengeluaran yang bersifat insidental yang belum tercatat, meskipun mereka sudah menghitung keuntungan atau kerugian setiap bulannya. Pekerjaan bersifat borongan dengan sistem make to Order atau membuat setelah ada pesanan. Terkhusus untuk pembuat teralis besi, karakteristik pesanan bervariasi sangat tinggi, masing-masing pesanan mensyaratkan ukuran dan tingkat ketumitan yang berbeda, sehingga seringkali membutuhkan bahan-bahan / campuran bahan khusus.

2. Kemampuan inovasi

Apabila dibandingkan dengan pengrajin logam yang memproduksi alat-alat pertanian atau pertukangan, pembuat teralis besi dan pengrajin hiasan-hiasan logam harus memiliki keahian khusus untuk memodifikasi produknya sesuai pesanan pelanggan.

3. Alur koordinasi dan tanggung jawab

Terkait dengan alur tanggung jawab, mereka mengaku sudah memiliki jalur koordinasi yang jelas dan bawahan mengaku merasa diberdayakan daripada dikendalikan. 


\section{Jam kerja}

Permasalahan pengaturan jam kerja, karena bersifat borongan maka jam kerja tidak dapat dipastikan, semua tergantung pada kebutuhan dan kecepatan menyelesaikan pesanan untuk pengjarin teralis besi dan pernak pernik hiasan logam, sedangkan untuk pembuat alat-alat pertanian dan pertukangan, biasanya pekerjaan dilakukan setelah selesai mengerjakan pekerjaan lain. Beberapa diantaranya juga mengaku konsistem bekerja mulai jam 8 pagi sampai jam 4 sore.

5. Sistem informasi

Untuk memonitor proses dan situasi kerjanya, para pengrajin logam sudah menerapkan beberapa alat sebagai sumber informasi walaupun masih sangat sederhana, antara lain : diagram alur untuk menentukan tahapan/proses pada masing-masing proyek pesanan pembelu, diagram sebab akibat untuk memonitor kondisi tertentu yang bersifat tidak rutin untuk menemukan penyebab dan menindaklanjuti dengan tindakan penyelesaian yang spesifik, menentukan level/derajat kepentingan atau prioritas pada proses tertentu yang dianggap perlu mendapat perhatian khusus dengan biaya yang paling besar, aktifitas yang memerlukan ketersediaan bahan baku yang sulit didapat, aktifitas yang memerlukan tambahan tenaga kerja, atau aktifitas yang membutuhkan tingkat konsentrasi yang tinggi.

d. Dimensi pengetahuan tentang pemungutan pajak

meskipun sudah memiliki pengetahuan tentang pajak pribadui maupun pajak badan, tetapi 5 pemilik usaha kerajinan logam, semuanya mengaku belum memiliki NPWP. Penyuluhan dan pembimbingan dari pemerintah daerah terkait pungutan pajak belum maksimal terealisasi, walaupun sudah pernah ada pelatihan dan sosialisasi penarikan pajak, baik itu pajak untuk pribadi maupun pajak badan usaha.

Pengrajin logam memberikan respon negative terhadap pertanyaan mengenai pajak. Menurut responden, adanya pemungutan pajak dinilai memberatkan, 2 diantara 8 responden seharusnya sudah mempunyai NPWP dan membayar pajak penghasilan karena omsetnya sudah mencapai 70 juta rupiah pertahun, namun kesadaran membayar pajak berlum ada bahkan dinilai memberatkan karena selalu dikaitkan dengan korupsi oleh pemenrintah dan tidak merasakan dampak yang baik.

\section{SIMPULAN}

Terdapat 4 dimensi dalam mengkaji kepemilikan pengetahuan keuangan oleh pengrajin logam di Propinsi Jawa Timur yaitu (1) dimensi pengetahuan mengenai istilah keuangan, (2) dimensi manajemen uang, (3) dimensi pencatatan keuangan dan sistem kerja, dan (4) dimensi pengetahuan tentang pemungutan pajak. Temuan kunci dalam penelitian ini adalah bahwa seorang pengusaha harus memiliki pengetahuan tentang keuangan meskipun hanya pada tingkat dasar.

Saran dari peneliti adalah (1) pengusaha harus meningkatkan pengetahuannya dengan mengikuti kursus pembuaran laporan keuangan ataupun pembelajaran secara otodidak melalui internet, (2) ihak pemerintah 
harus lebih dalam melakukan pembinaan yang menjangkau sampai perbaikan proses produksi dan pembinaan pembuatan catatan keuangan, karena selama ini pemerintah hanya fokus pada pemasaran padahal produk-produk alat pertanian dan pertukangan dari hasil produksi pengrajin logam ini kalah bersaing dibandingkan produk-produk instri besar dan produk impor (3) saran lain untuk pemerintah, dapat memasukkan praktik produksi pengolahan logam dasar pada kurikulum sekolah menengah kejuruan agar dapat menatik minat siswa peserta didik untuk menjadi pengusaha pengrajin logam dan memproduksi alat-alat berbasis logam.

\section{DAFTAR RUJUKAN}

Afifuddin, Saebani, Benny Ahmad. 2009. Metodologi Penelitian Kualitatif. Pustaka Setia Press, Bandung.

Altintas, Kadir Murat, (2011). "The Dunamic of Financial Literacy Within the Framework of Personal Finance : An Analysis Among Turkish University Students." African Journal of Business Management, Vo. 2, No. 26, pp. 10483-10491.

Babbie, E. 1998. The Practice of Social Research. Belmont, CA : Wadsworth. Business Management, 24 (4) : $1-8$.

Creswell, J.W. 2007. Qualitative Inquiry and Research Design : Choosing Among Five Approach, Second Edition. Sage Publication, California, USA.

Kaplan, J.M. 2003. Paterns of Entrepreneurship. Upper Saddle River, NJ: Wiley, USA.

Lusardi, Annamaria, Mitchell, (2007). "Financial Literacy and Retirement Preparedness: Evidence and Implications for Financial Education Programs".Michigan Retirement Research Center Research. Paper No. WP 2006-144.

Susanti. 2014. "Faktor-faktor yang berpengaruh terhadap Literasi Keuangan dan Perilaku Keuangan Siswa SMA Negeri di Surabaya." Disertasi tidak diterbitkan. Malang: PPS UM. 